\title{
Identification and Characterization of Subpopulations of Lymphocytes in Human Peripheral Blood after Fractionation on Discontinuous Gradients of Albumin
}

\author{
THE CELLULAR DEFECT IN X-LINKED \\ AGAMMAGLOBULINEMIA
}

\author{
R. S. Geha, F. S. Rosen, and E. Merler \\ From the Immunology Division, Department of Medicine, Children's Hospital \\ Medical Center, and the Departments of Pediatrics, and Microbiology and \\ Molecular Genetics, Harvard Medical School, Boston, Massachusetts 02115
}

A B S T R A C T Normal human peripheral blood lymphocytes were separated on discontinuous gradients of 17$35 \%$ bovine serum albumin (BSA) into nine fractions. Three subpopulations of lymphocytes were obtained. One occupies the top third of the gradient (fractions 1-3, 17$23 \% \mathrm{BSA}$ ) and is rich in cells characterized by a high spontaneous rate of DNA synthesis and by the ability to give rise to colony-forming units. The middle portion of the gradient (fractions 4 and 5, 23-27\% BSA) is rich in thymus-derived ( $\mathrm{T}$ ) lymphocytes identified by their vigorous response to mitogens and by their ability to form rosettes with sheep erythrocytes (E). The third subpopulation at the bottom of the gradient (fractions $6-9,27-35 \%$ BSA) is rich in bone marrow-derived (B) lymphocytes capable of staining with fluorescent antiimmunoglobulin antisera and of forming rosettes with EAC1423.

The peripheral blood lymphocytes of five boys with proved X-linked agammaglobulinemia and two with probable X-linked agammaglobulinemia were found to be totally deficient in B lymphocytes (fractions 6-9) and lacked the subpopulation identified by immunofluorescent staining or rosette formation with EAC1423. One boy with proved X-linked agammaglobulinemia and two with probable X-linked agammaglobulinemia possessed a normal amount of circulating $B$ lymphocytes.

Dr. Geha is the recipient of a postdoctoral fellowship from the Lebanese Research Council, and for part of this study, of a U. S. Public Health Service International Fellowship 1-FO5-TW-1871.

Received for publication 13 December 1972 and in revised form 28 February 1973.

\section{INTRODUCTION}

Lymphocytes in peripheral blood are functionally as well as morphologically heterogeneous (1). Laboratory experiments in animals, and various clinical abnormalities show that one subpopulation of lymphocytes is thymus dependent ( $T$ lymphocytes $)^{1}$ and is critical to the manifestations of cellular immunity $(2,3)$, while another subpopulation is bursa or bone marrow derived ( $B$ lymphocytes) and is responsible for development of humoral immunity $(4,5)$. The existence of a third subpopulation of immature, less differentiated, circulating lymphocytes is still questionable because suitable methods for identifying such cells are less well defined. The separation of these two or three subpopulations of lymphocytes in relatively pure form is of both theoretical and practical interest.

Because the presence of the theta antigen marker on the surface of murine $T$ lymphocytes $(6,7)$ makes identification of such cells feasible, analogous markers are being sought for human $T$ cells. We have applied the technique of discontinuous albumin gradient centrifugation to human peripheral blood in an attempt to assess the number, function, and distribution of different sub-

${ }^{1}$ Abbreviations used in this paper: $\mathrm{B}$, bone marrow-derived; BSA, bovine serum albumin; CFU, colony-forming units; E, sheep erythrocyte; FITC, fluorescein isothiocyanate; HSA, human serum albumin; PBL, peripheral blood lymphocytes; PBS, phosphate-buffered saline; PHA, phytohemagglutinin; PWM, pokeweed mitogen; SI, stimulation index; $T$, thymus-derived; $T_{0}$, initial rate of DNA svnthesis. 
populations of circulating lymphocytes in normal individuals and boys with $\mathrm{X}$-linked agammaglobulinemia.

\section{METHODS}

Purification of peripheral blood lymphocytes (PBL). Heparinized blood obtained from healthy adult donors was sedimented for $1 \mathrm{~h}$ in the presence of dextran. Leukocyterich plasma was separated and transferred to a $50 \times 3 \mathrm{~cm}$ glass column half-filled with glass beads and prewarmed to $37^{\circ} \mathrm{C}$. The cell suspension was allowed to soak through the glass bead layer for $30 \mathrm{~min}$ and eluted with several volumes of medium 199 (8). The eluate consisted of a cell suspension containing more than $90 \%$ lymphocytes. Viability was determined by trypan blue exclusion. In some experiments, blood obtained from a single donor was divided into two portions. Lymphocytes were purified from one portion by the above method, and from the second in a Ficoll-Hypaque gradient (9). 4 parts of heparinized blood diluted 1:1 with Hanks's balanced salt solution were layered in sterile glass tubes over 3 parts of a solution obtained by mixing 10 parts of $33.9 \%$ Hypaque-M and 24 parts of $9 \%$ Ficoll. The tubes were centrifuged at $400 \mathrm{~g}$ and room temperature for $40 \mathrm{~min}$. The leukocytes at the interface were collected, washed twice in medium 199, resuspended, and tested for viability. Total and differential cell counts were determined.

Fractionation of cells on gradients of bovine serum albumin $(B S A)$. Gradients were prepared by the modification of the method of Dicke et al., as described by August, Merler, Lucas, and Janeway (10). The gradients were formed in $16 \times 125 \mathrm{~mm}$ sterile plastic tubes by layering $1 \mathrm{ml}$ of the albumin solutions in $2 \%$ decrements, starting with $35 \%$ and ending with $19 \%$ solutions. $5 \times 10^{8}$ cells were suspended in $1 \mathrm{ml}$ of $17 \% \mathrm{BSA}$ and layered on top of the gradient. Tubes were centrifuged at $10^{\circ} \mathrm{C}$ and $900 \mathrm{~g}$ for $45 \mathrm{~min}$. Nine fractions were obtained: fraction 1 represents cells at the interface between the 17 and $19 \%$ albumin, and fraction 9, those between 33 and $35 \%$ albumin. Cells from each fraction were collected from the interface with a Pasteur pipette, washed twice in medium 199, and then diluted to a suitable concentration in complete RPMI1640 culture medium. For each of the fractions, cell viability was determined, and coverslip smears were made and stained, with Wright's stain.

Colony-forming units $(C F U)$. Fractionated lymphocytes were assayed for colony-forming units (CFU) by a modification of the method of Metcalf (11). Complete Dulbecco's medium with $20 \%$ fetal calf serum and antibiotics $(50 \mathrm{U} / \mathrm{ml}$ penicillin, $50 \mu \mathrm{g} / \mathrm{ml}$ streptomycin, $50 \mathrm{U} / \mathrm{ml} \mathrm{my-}$ costatin, and $50 \mu \mathrm{g} / \mathrm{ml}$ kanamycin) was supplemented with $20 \%$ complete Dulbecco's medium that had been removed from 3-day cultures of $\mathrm{HeLa}$ cells and filtered through $0.45 \mu$ filters (Millipore Corp., Bedford, Mass.). Two ml of a $0.8 \%$ agarose solution were plated out in $60-\mathrm{mm}$ tissue culture Petri dishes and overlaid with $1 \times 10^{6}$ fractionated lymphocytes dispersed in $1 \mathrm{ml}$ of 0.3 agarose. An additional $1 \mathrm{ml}$ of $0.3 \%$ agarose was added every 3 days. The number of CFU was counted with an inverted microscope at 4,7 , and 10 days.

Determination of spontaneous cellular mitotic activity and of cellular response to mitogens. Cells were suspended in complete RPMI culture medium at a final concentration of $1 \times 10^{8} \mathrm{cells} / \mathrm{ml}$. 1-ml cultures were set up in $12 \times 75 \mathrm{~mm}$ Falcon plastic tubes. (Falcon Plastics, Division of B-D Laboratories, Inc., Los Angeles, Calif.) and incu- bated at $37^{\circ} \mathrm{C}$ in a humidified atmosphere of $5 \% \quad \mathrm{CO}_{2}$ and air.

For each of the nine lymphocyte fractions, as well as for unfractionated lymphocytes, a total of seven different duplicate cultures were set up. The first set was used to determine the initial rate of DNA synthesis $\left(T_{0}\right)(12)$. Each of these tubes was incubated with $1 \mu \mathrm{Ci}$ of $\left[{ }^{3} \mathrm{H}\right]$ thymidine for $16 \mathrm{~h}$. Three other sets were divided as follows: in one, a control, cells were incubated alone, in a second, with phytohemagglutinin-M (PHA), and in a third, with pokeweed mitogen (PWM). PHA and PWM were both added to a final concentration of $1: 500$. Cultures were pulsed at the $72 \mathrm{nd} \mathrm{h}$ with $\left[{ }^{3} \mathrm{H}\right]$ thymidine $(1 \mu \mathrm{Ci} / \mathrm{ml})$ and harvested $16 \mathrm{~h}$ later. Three more duplicate cultures were kept for 6 days: a control set, a set incubated with tetanus toxoid $(10 \mu \mathrm{g} / \mathrm{ml})$, and a third incubated with mitomycin $\mathrm{C}$-treated allogeneic cells at a final concentration of $4 \times$ $10^{8}$ cells/culture (13). At the end of 6 days, cells were pulsed with $\left[{ }^{3} \mathrm{H}\right]$ thymidine $(1 \mu \mathrm{Ci} / \mathrm{ml})$ and harvested $16 \mathrm{~h}$ later.

The extent of cellular proliferation of lymphocytes in cultures was estimated by assaying for incorporation of $\left[{ }^{3} \mathrm{H}\right]$ thymidine into DNA by the filter paper disk technique. At the time of harvest, cells in each culture were resuspended and $0.1 \mathrm{ml}$ aliquots pipetted in duplicate onto Whatman filter paper No. 3 disks $2.3 \mathrm{~cm}$ in diameter. After being dried, the disks were immersed for at least $1 \mathrm{~h}$ in $10 \%$ trichloracetic acid containing an excess of nonradioactive thymidine. This was followed by two washes in $5 \%$ trichloracetic acid for $15 \mathrm{~min}$ each, two washes in ethanol: acetone $(1: 1)$ at $37^{\circ} \mathrm{C}$ for $30 \mathrm{~min}$ each, and one wash in acetone for $15 \mathrm{~min}$. The disks were then dried and the radioactivity estimated by liquid scintillation spectrometry using a Tri-Carb Liquid Scintillation Spectrometer (Packard Instrument Co., Downers Grove, Ill.). A blank disk subjected to the same washing procedure served to assay for background radioactivity. Counts per minute (cpm) on each disk were converted after background subtraction to give cpm per culture of $10^{6}$ cells.

Measurement of antigen uptake by $P B L$. Cultures to which ${ }^{125}$ I-labeled tetanus toxoid $(10 \mu \mathrm{g} / \mathrm{ml})$ or ${ }^{125} \mathrm{I}$-labeled human serum albumin $(10 \mu \mathrm{g} / \mathrm{ml})$ were added contained $8 \times 10^{8}$ lymphocytes $/ \mathrm{ml}$ of medium 199 supplemented with $10 \%$ fetal calf serum and $10^{-2} \mathrm{~mol} / \mathrm{liter}$ sodium azide. $1-\mathrm{ml}$ cultures in $16 \times 125 \mathrm{~mm}$ Falcon plastic tubes were incubated on a roller drum for $4 \mathrm{~h}$. At the end of this period, cells were collected by centrifugation at $200 \mathrm{~g}$ for $10 \mathrm{~min}$, washed three times with medium 199 , and the radioactivity bound to the cells assayed in a $\mathrm{NaI}$ crystal scintillation counter (Packard Instrument Co., Inc., Downers Grove, III.). $\mathrm{Cpm}$ were converted to micrograms of protein taken up by the cells.

Immunofluorescent staining. The following fluoresceinconjugated reagents were used: rabbit antihuman $\mathrm{IgG}$, an IgM agglutinator with specificity against the $F_{c}$ portion of IgG but without $\mathrm{Gm}$ specificity (obtained from the serum of a 14-year-old) (14), goat antihuman IgM (absorbed with Ig A myeloma, IgG myeloma, and kappa and lambda Bence Jones proteins), and human serum albumin (HSA). $0.1 \mathrm{ml}$ of conjugated antiserum was added to an equal volume of a suspension containing $2 \times 10^{7}$ cells $/ \mathrm{ml}$ of medium 199 supplemented with $5 \%$ fetal calf serum. Cells were incubated for $45 \mathrm{~min}$ at room temperature, washed three times in medium 199, and transferred to a glass slide in a drop of glycerol : water $(9: 1)$.

Slides were examined using a Zeiss fluorescent microscope with a tungsten lamp source and a KP-490 filter 
(Carl Zeiss, Inc., New York). At least 200 cells were examined and the percent of fluorescent cells recorded.

Rosette formation by $P B L$. Erythrocyte (E) intermediates EA, EAC14, and EAC1423 (subsequently referred to EAC3) were prepared using human components of complement (15) and adjusted to a final concentration of $0.5 \%$ in phosphate-buffered saline (PBS). Lymphocyte suspensions previously treated with $0.87 \% \mathrm{NH}_{4} \mathrm{Cl}$ to lyse red blood cells were adjusted to $2 \times 10^{6}$ cells $/ \mathrm{ml}$ in PBS containing $10 \%$ serum from a donor with type $\mathrm{AB} \mathrm{Rh}+$ erythrocytes, and absorbed 3 times with sheep erythrocytes.

Equal volumes of lymphocyte and $\mathrm{E}$ or $\mathrm{E}$-intermediate suspensions were incubated for $30 \mathrm{~min}$ at $37^{\circ} \mathrm{C}$, centrifuged at $200 \mathrm{~g}$ for $5 \mathrm{~min}$ at $10^{\circ} \mathrm{C}$, and the pellets incubated at $0^{\circ}$ for $1 \mathrm{~h}$. Cells were then resuspended and examined microscopically. Lymphocytes intimately associated with more than four erythrocytes were considered to have formed rosettes. A total of four chambers in an improved Neubauer hemacytometer $\left(3.6 \mathrm{~mm}^{3}\right)$ were examined to define the percentage of rosette-forming lymphocytes (16).

Purification of EAC3 rosette-forming cells. After incubation of $10 \times 10^{6}$ lymphocytes with EAC3 as described above, cell pellets were resuspended in $1 \mathrm{ml}$ of RPMI and layered on a simple albumin gradient consisting of two layers ( 33 and $23 \% \mathrm{BSA}$ ), each $1.5 \mathrm{ml}$. The gradient was centrifuged at $15,000 \mathrm{~g}$ for $30 \mathrm{~min}$ at $4^{\circ} \mathrm{C}$. LymphocyteEAC3 rosettes, sedimenting at the bottom of the gradient, were dissociated by treatment with a $1: 10$ dilution of goat antihuman $\mathrm{C} 3$ for $30 \mathrm{~min}$ at $37^{\circ} \mathrm{C}$ (17).

Study of $P B L$ from patients with X-linked agammaglobulinemia. PBL from six boys with proved X-linked agammaglobulinemia aged $5,9,13,14,15$, and $21 \mathrm{yr}$ were fractionated on BSA gradients and studied for cell distribution, in vitro response to mitogens, rosette formation with sheep cell intermediates, and immunofluorescent staining. In each of the six boys, the diagnosis of X-linked agammaglobulinemia was made on the basis of the following criteria: early onset of the disease, circulating levels of immunoglobulins below $1 \mathrm{mg} / \mathrm{ml}$, histology of antigenstimulated lymph nodes showing absence of germinal centers of follicular structures and plasma cells, and presence of affected lateral male relatives (uncles and nephews).

$\mathrm{PBL}$ from four boys with probable $\mathrm{X}$-linked agammaglobulinemia aged $8,12,17$, and $19 \mathrm{yr}$ were studied in the same fashion. One of the four boys had an affected brother. In the remaining three patients, there was a negative family history of the disease. In each of the four boys, the diagnosis of probable $x$-linked agammaglobulinemia was made on the basis of very early onset of disease and on the basis of the histology of antigen-stimulated lymph nodes which showed absent germinal centers and absent plasma cells.

Reagents and culture media. Preservative-free sodium heparin was obtained as Panheprin $(20,000 \mathrm{U} / \mathrm{ml}$ from $\mathrm{Ab}-$ bott Laboratories, North Chicago, Ill.). Dextran was obtained as $6 \% \mathrm{wt} / \mathrm{vol}$ in saline from McGraw Laboratories, Glendale, Calif. Superbrite glass beads were purchased from 3M Company, St. Paul, Minn. Ficoll was obtained from Pharmacia Company, Uppsala, Sweden; and Hypaque$M$ (as diatrizoate sodium $50 \% \mathrm{wt} / \mathrm{vol}$ in water), from Winthrop Laboratories, Division of Sterling Drug, Inc., New York. PHA and PWM were products of Difco Laboratories, Detroit, Mich. Tetanus toxoid was provided by Massachusetts Biological Laboratories, Boston, Mass. The preparation used (lot LP-346) contained $2.3 \mathrm{mg}$ of protein $/ \mathrm{ml}$. Half of this protein was precipitable by human hyperimmune antitetanus antibodies. BSA in powder form and thymidine were products of Sigma Chemical Company, St. Louis, Mo.
Mitomycin-C and fluorescein isothiocyanate (FITC) were purchased from Nutritional Biochemicals Corporation, Cleveland, Ohio. Radioactive $\left[{ }^{3} \mathrm{H}\right]$ thymidine $(1.9 \mathrm{Ci} / \mathrm{mmole})$ and $\left[{ }^{125} \mathrm{I}\right]$ sodium iodide of high specific activity were obtained from New England Nuclear, Boston, Mass. Agarose was obtained from Marine Colloids, Rockland, Maine. Sheep erythrocytes in Alsever's solution, mycostatin, kanamycin, and penicillin-streptomycin mixture $(5,000 \mathrm{U} / \mathrm{ml})$ were purchased from Microbiological Associates, Bethesda, Md.

Medium 199, Dulbecco's medium, and fetal calf serum were products of Microbiological Associates. Complete RPMI culture medium for lymphocyte cultures was made by adding $18 \mathrm{ml}$ of heat-inactivated serum from a donor with type $\mathrm{AB} \mathrm{Rh}+$ erythrocytes and $2 \mathrm{ml}$ of penicillinstreptomycin mixture to $100 \mathrm{ml}$ of RPMI-1640 medium obtained from Grand Island Biological Co., Grand Island, N. Y.

\section{RESULTS}

Fractionation of peripheral lymphocytes in BSA gradients. There was excellent $(80-90 \%)$ recovery of lymphocytes from peripheral venous blood after passage through glass beads; the resulting suspension contained more than $90 \%$ lymphocytes, the remainder being neutrophils and a few monocytes. The distribution of cells in nine fractions obtained from the BSA gradients is shown in Fig. 1a. Recentrifugation of any single fraction in a second BSA gradient always resulted in a reproducible pattern. Fraction 4 always contained more than $50 \%$ of the total number of lymphocytes recovered from the gradient, and fraction 6 never exceeded $10 \%$.

Microscopic examination revealed that cells from the top of the gradient (fractions 1-3) were mainly mediumand large-size lymphocytes $9-12 \mu \mathrm{m}$ in diameter with a fair amount of cytoplasm (30-40\% of the total cell volume). Cells from the middle part of the gradient (fractions 4 and 5) were composed of intermediate- and small-size lymphocytes in an approximate ratio of $20: 80$. Their size ranged from 7 to $9 \mu \mathrm{m}$, and they had scant cytoplasm. Fractions $6-9$ consisted exclusively of very small lymphocytes, $7 \mu \mathrm{m}$ in diameter, with very scant cytoplasm. Contaminating neutrophils were found in the lower fractions, 7 and 8 , while the few contaminating monocytes remained in the uppermost fractions, 2 and 3. Erythrocytes sedimented in fractions 8 and 9.

Lymphocyte spontaneous mitotic activity and response to mitogens. Cells in the upper fractions, $1-3$, had the highest initial rate of DNA synthesis $\left(T_{0}\right)$ (Fig. $1 b$ ). As shown in Fig. 1b, they continued to have a high rate of thymidine incorporation after 6 days in culture in the absence of any mitogen. Cells from the middle and lower parts of the gradient had a low $T_{0}$; the lowest $T_{0}$ values were obtained from cells in fractions $6-9$.

After stimulation by either PHA or PWM, cells from each of the nine fractions exhibited increased $\left[{ }^{3} \mathrm{H}\right]$ thymidine incorporation (Fig. 1c). When results were ex- 

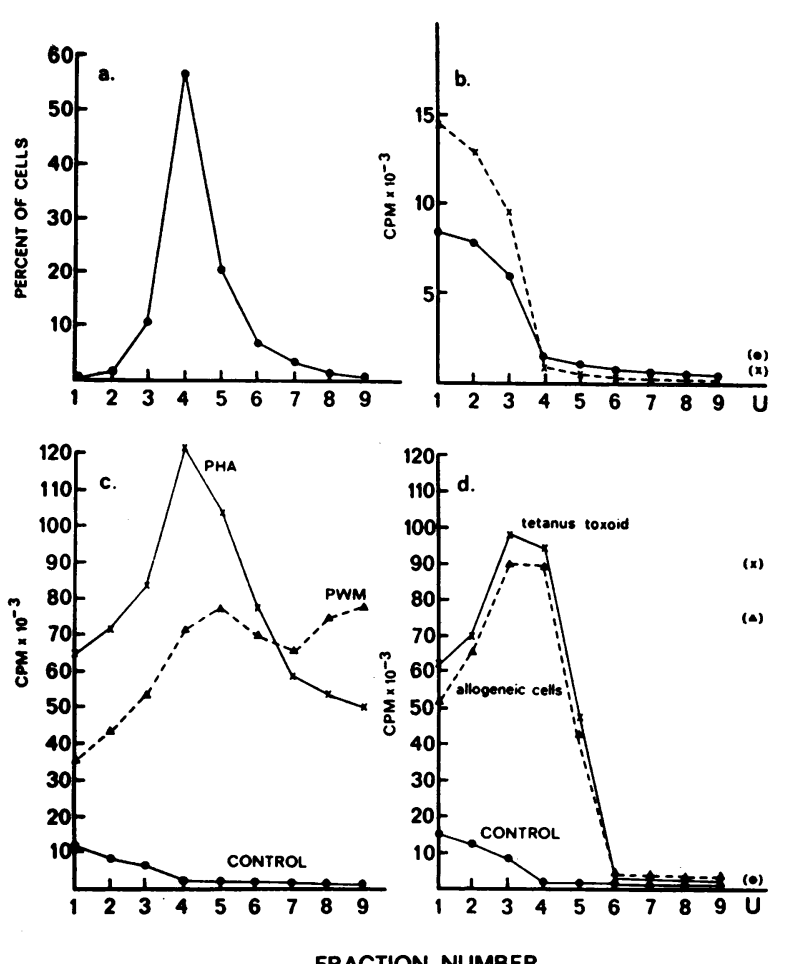

FRACTION NUMBER

Figure 1 Response in vitro of human PBL separated into fractions by centrifugation in a discontinuous gradient of $17-35 \%$ BSA. (a) Relative distribution of lymphocytes after purification by passage through glass beads. (b) Spontaneous incorporation of $\left[{ }^{3} \mathrm{H}\right]$ thymidine into DNA during 16-h incubation starting after $0 \mathrm{~h}$ in culture $\left(T_{0}\right.$, solid line) and after 6 days in culture (dashed line). (c) Incorporation of $\left[{ }^{3} \mathrm{H}\right]$ thymidine into DNA after 3-day incubation with PHA and PWM. (d) Incorporation of $\left[{ }^{3} \mathrm{H}\right]$ thymidine into DNA after 6-day incubation with tetanus toxoid, 10 $\mu \mathrm{g} / \mathrm{ml}$ and allogeneic cells. Points, crosses, and triangles in parentheses represent values for unfractionated (U) PBL.

pressed as stimulation indices (SI) (where SI equals the number of cpm of $\left[{ }^{3} \mathrm{H}\right]$ thymidine incorporated by stimulated cultures per number of cpm of $\left[{ }^{3} \mathrm{H}\right]$ thymidine incorporated by unstimulated cultures), the SI was much lower for cells in the uppermost fractions (1-3) than for cells in the rest of the gradient (Table I). Incubation of fractions 1-3 with various dilutions of the standard concentration of PHA and PWM did not result in increased SI. When cultures were stimulated with specific antigen or with mitomycin C-treated allogeneic cells, maximal response occurred in fractions 4 and 5 , and intermediate response occurred in fractions $1-3$. There was not response in the lower fractions, 6-9.

Colony-forming units. Only cells in fractions 1-3 gave rise to colonies (Table II). As many as $1.1 \%$ of these cells were able to propagate in long-term culture in semisolid medium. Maximal colony size was achieved by
TABLE I

PHA Response of Human PBL Fractionated on BSA Gradients*

\begin{tabular}{crrr}
\hline \multirow{2}{*}{$\begin{array}{c}\text { BSA } \\
\text { fraction }\end{array}$} & \multicolumn{2}{c}{$\left[{ }^{3} \mathrm{H}\right]$-thymidine per $10^{6}$ cells } \\
\cline { 2 - 3 } & Control & PHA & SI \\
\hline & \multicolumn{2}{c}{$c p m$} & \\
$\mathrm{U} \ddagger$ & 1,200 & 97,520 & 81.0 \\
1 & 10,520 & 65,100 & 6.2 \\
2 & 8,310 & 71,100 & 8.6 \\
3 & 5,680 & 85,150 & 15.1 \\
4 & 1,110 & 123,700 & 120.4 \\
5 & 1,050 & 104,800 & 99.8 \\
6 & 970 & 78,600 & 81.0 \\
7 & 910 & 59,300 & 65.3 \\
8 & 850 & 53,200 & 62.6 \\
9 & 760 & 51,550 & 67.6 \\
\hline
\end{tabular}

* Values represent the average of 11 experiments.

$\ddagger U$ represents unfractionated lymphocytes.

day 7 of culture and ranged from 8 to 200 cells/colony. Cells found in 7-day-old colonies possessed an oval nucleus and showed no staining with myeloperoxidase. By day 10 of culture, most colonies stopped growing and started to degenerate.

Antigen uptake by lymphocytes. Fig. $2 a$ depicts the uptake of radioactive antigen by cells in different fractions of the gradient. $85 \%-90 \%$ of the cell-bound radioactivity was found to be specifically precipitable with an antibody to tetanus toxoid. ${ }^{2}$ There was no uptake of $\left[{ }^{125} \mathrm{I}\right]$ HSA, to which cell donors were not immune, by any of the cell fractions. Uptake of $\left[{ }^{125} \mathrm{I}\right]$ tetanus toxoid occurred mainly in fractions 6-8. This increased uptake in the lower fractions of the gradient was due neither to increased cell death nor to phagocytosis of antigen-antibody complexes by contaminating neutrophils, as all experiments were done in azide to inhibit neutrophil metabolism. Cell viability at the end of the experiment was the same in all fractions and exceeded $85 \%$. The calculated amount of antigen taken up by the small lymphocytes in layers $6-8$ averaged $0.4 \mu \mathrm{g} / 10^{7}$ cells or an average of $10^{5}$ molecules/cell.

Rosette formation with $E$ and EAC3. As shown in Fig. $2 b$ and $c$, rosette formation with erythrocytes occurred mainly with cells present in the upper and middle fractions of the gradient, while rosette formation with EAC3 occurred mainly with cells present in the lower portions of the gradient (fractions 6-9). There was very little rosette formation with the intermediates EA and EA14, which were used as controls.

Results of immunofluorescent staining of $P B L$. The only cells exhibiting staining with the anti-IgG and

${ }^{2}$ Rubinstein, A., and E. Merler. Unpublished observation. 
TABLE II

Colony Formation by Fractionated Human $P B L^{*}$

\begin{tabular}{cccc}
\hline BSA fraction & Cells plated & CFU & $\%$ \\
\hline $1+2+3$ & $1 \times 10^{6}$ & $1.1 \times 10^{4}$ & 1.1 \\
$4+5$ & $1 \times 10^{6}$ & 0 & 0 \\
$6+7+8$ & $1 \times 10^{6}$ & 0 & 0
\end{tabular}

* Values represent the average of two experiments.

anti-Fc antisera were those found in layers 6-9 (Fig. $2 d)$. The predominant staining pattern was one of speckles uniformly distributed in a ring pattern. A number of lymphocytes exhibited fluorescence concentrated at one pole (cap formation).

Separation of EAC3-reactive from $E A C 3$ nonreactive lymphocytes in fractions 6-9 of the BSA gradient. As shown in Table III, EAC3-reactive lymphocytes formed the majority of cells found in fractions 6-9, stained heavily with anti-Fc antiserum (78\%), and failed to respond to PHA (SI 3.1). Treatment of lymphocyte-EAC3 rosettes with the anti-C3 antiserum resulted in the recovery of only $20 \%$ viable lymphocytes which also failed to respond to PHA. The PHA response exhibited by cells in fractions 6-9 was accounted for by a minor population $(22 \%)$ of EAC3-nonreactive, nonimmunofluorescent, PHA-responsive lymphocytes.

Behavior of $P B L$ in X-linked agammaglobulinemia. In five of the six cases with proved X-linked agammaglobulinemia and in two of the four cases with probable $\mathrm{X}$-linked agammaglobulinemia, unfractionated lymphocytes failed to form rosettes with EAC3 and to stain with fluorescent antisera to Fc, IgG, and IgM (Tables IV and V). After BSA gradient centrifugation of PBL from the seven patients with absent immunofluorescent cells, less

TABLE III

Separation of $P B L$ in Fractions 6-9 of the BSA Gradient on the Basis of their Reactivity with EAC1423*

\begin{tabular}{|c|c|c|c|c|}
\hline \multirow[t]{2}{*}{ Cell population } & \multicolumn{2}{|c|}{ Cell distribution } & \multirow{2}{*}{$\begin{array}{c}\begin{array}{c}\text { Cells } \\
\text { stained } \\
\text { with } \\
\text { fluorescent } \\
\text { anti-Fc }\end{array} \\
\%\end{array}$} & \multirow[t]{2}{*}{$\begin{array}{l}\text { PHA } \\
\text { response } \\
\text { (SI) }\end{array}$} \\
\hline & Total number & $\%$ & & \\
\hline $\begin{array}{l}\text { Fractions 6-9 } \\
\text { EAC3 nonreactive }\end{array}$ & $21 \times 10^{8}$ & 100 & 55 & 52.3 \\
\hline cells & $4.5 \times 10^{6}$ & 22 & 3 & 86.2 \\
\hline $\begin{array}{l}\text { EAC } 3 \text { reactive cells } \\
\text { EAC } 3 \text { reactive cells }\end{array}$ & $15.5 \times 10^{6}$ & 78 & 87 & 3.1 \\
\hline treated with anti-C3 & $3 \times 10^{6}$ & & 92 & 2.4 \\
\hline
\end{tabular}

* Separation of EAC3-reactive from EAC3-nonreactive cells was carried out as described in Methods. EAC3-nonreactive cells were found at the interface of the two albumin layers, while EAC3-reactive cells sedimented to the bottom of the gradient. PHA stimulation results are expressed as stimulation indices.

1730 R. S. Geha, F. S. Rosen, and E. Merler than $1 \%$ of the cells sedimented in fractions $6-9$ of the gradient (Tables V and VI, and Fig. 3). In normal individuals, $10-15 \%$ of $\mathrm{PBL}$ are found in these same fractions. In all seven cases, the few lymphocytes found in fractions 6-9 failed to stain with fluorescent antisera or to form rosettes with EAC3 (Table IV). PBL from one patient (D.P.) with proved X-linked agammaglobulinemia and from two of the four patients with probable $\mathrm{X}$-linked agammaglobulinemia showed a normal distribution after BSA gradient centrifugation, and contained a normal number of fluorescent cells and of EAC3-reactive cells (Tables IV, V, and VI). Lymphocytes from all patients responded normally to stimulation with PHA and tetanus toxoid and formed normal numbers of rosettes with sheep erythrocytes (Table IV).
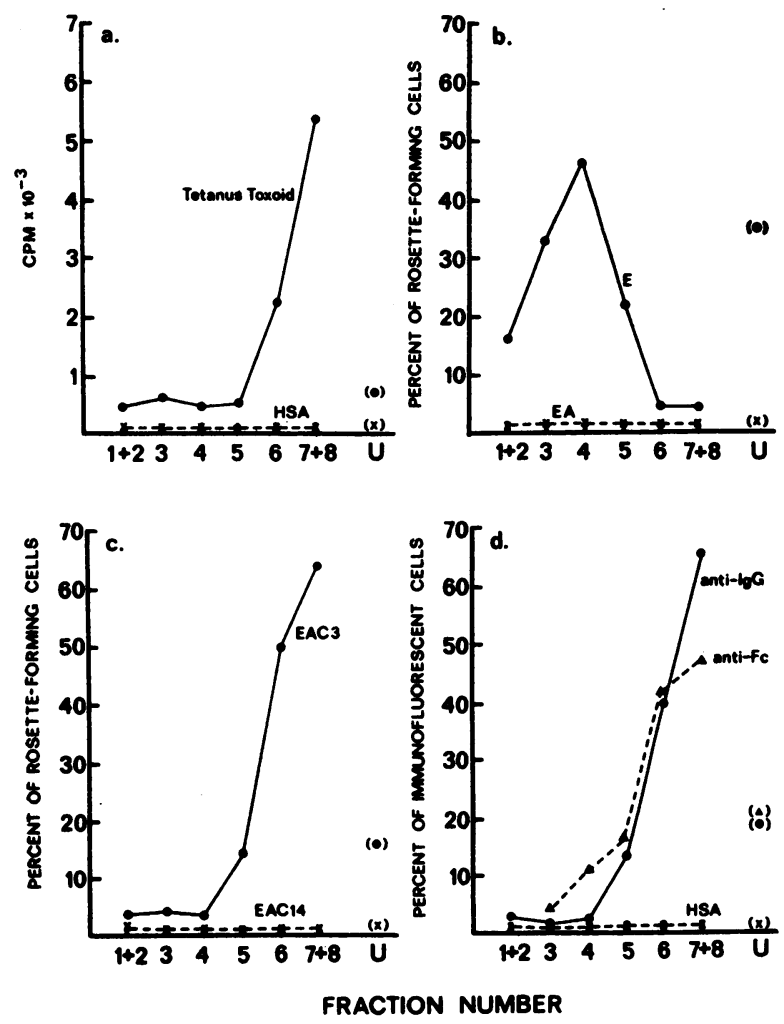

FIGURE 2 Responses in vitro of human PBL separated into fractions by centrifugation in a discontinuous gradient of $17-35 \%$ BSA. (a) Uptake of ${ }^{125}$ I-labeled antigen (tetanus toxoid) compared to control protein by $10^{7}$ lymphocytes. Values represent the average of four experiments. (b) Rosette formation with sheep erythrocytes (E) compared to EA as control. Values represent the average of three experiments. (c) Rosette formation with EAC3 compared to EAC14 (control). Values represent the average of four experiments. $(d)$ Immunofluorescent staining with fluorescein conjugates of anti-IgG, anti-Fc, and HSA. Values represent the average of three experiments. Points, crosses, and triangles in parentheses represent the values for unfractionated (U) PBL. 
TABLE IV

In Vitro Response of PBL from Normal Individuals and from Patients with Proved X-Linked Agammaglobulinemia (X-LA)

\begin{tabular}{|c|c|c|c|c|}
\hline \multirow[b]{2}{*}{$\begin{array}{c}\text { BSA } \\
\text { fraction }\end{array}$} & \multirow[b]{2}{*}{ In vitro test } & \multicolumn{3}{|c|}{ Response } \\
\hline & & Normal* & X-LA $\ddagger$ & $\begin{array}{c}\text { X-LA } \\
\text { (D. P.)§ }\end{array}$ \\
\hline $\mathrm{U}$ & PHA $(S I)$ & 81.0 & 86.2 & 91.3 \\
\hline $\mathrm{U}$ & Tetanus toxoid $(S I)$ & 53.1 & 52.4 & 60.8 \\
\hline $\mathrm{U}$ & E rosette-forming cells $(\%)$ & 30.3 & 31.4 & 33.7 \\
\hline $\mathrm{U}$ & EAC3 rosette-forming cells $(\%)$ & 15.2 & 2.2 & 11.5 \\
\hline $\mathrm{U}$ & Cells fluorescent with anti-IgG FITC $(\%)$ & 19.0 & 0.1 & 10.1 \\
\hline $\mathrm{U}$ & Cells fluorescent with anti-IgM FITC $(\%)$ & 9.4 & 0.1 & 6.1 \\
\hline $6-9$ & EAC3 rosette-forming cells (\%) & 57.2 & 0.9 & 54.6 \\
\hline $6-9$ & Cells fluorescent with anti-IgG FITC $(\%)$ & 52.3 & 0.0 & 50.4 \\
\hline $6-9$ & Cells fluorescent with anti-IgM FITC $(\%)$ & & 0.1 & 27.2 \\
\hline
\end{tabular}

* Values for normal PBL represent the average of six experiments.

¥ Values represent the average obtained from the study of the PBL of the five patients with X-linked agammaglobulinemia and deficient fractions 6-9 of the BSA gradient.

$\S$ Values obtained from the single X-linked agammaglobulinemia patient (D. P.) who had a normal BSA gradient distribution of PBL.

\section{DISCUSSION}

It is possible to separate human blood lymphocytes into three functionally distinct subpopulations by the technique of density gradient centrifugation. Of these subpopulations, one is rich in immature, poorly differentiated cells; another, in T lymphocytes; and the third, in B lymphocytes.

Cells found in the uppermost fractions (1-3) of the BSA gradient exhibit progenitor cell characteristics. These are large size, very high spontaneous rate of DNA synthesis (Fig. 1b), diminished responsiveness to mitogens (Table II), and the unique ability to give rise to CFU when cultured in semisolid medium (Table I). The exact nature, as well as the exact number, of CFU precursor cells are unknown. Morphologic study of the cells found in 7-day-old colonies was unrevealing, as these cells still looked very immature and failed to stain with myeloperoxidase. It is possible that these cells might dif-

TABLE V

Behavior of $P B L$ from Four Patients with Probable $X$-Linked Agammaglobulinemia

\begin{tabular}{|c|c|c|c|c|c|}
\hline \multirow[b]{2}{*}{ In vitro test } & \multirow[b]{2}{*}{$\begin{array}{l}\text { Normal } \\
\text { adults }\end{array}$} & \multicolumn{4}{|c|}{$\begin{array}{l}\text { Probable X-linked agamma- } \\
\text { globulinemia }\end{array}$} \\
\hline & & $\begin{array}{l}\text { D. McD. } \\
19 \mathrm{yr}\end{array}$ & $\begin{array}{l}\text { H. T. } \\
17 \mathrm{yr}\end{array}$ & $\begin{array}{l}\text { R. L. } \\
12 \mathrm{yr}\end{array}$ & $\begin{array}{l}\text { L. P. } \\
8 \text { yr }\end{array}$ \\
\hline $\begin{array}{l}\text { Cells in fractions } 6-9 \text { of } \\
\text { the BSA gradient }(\%)\end{array}$ & 12.1 & 0.9 & 1.1 & 13.7 & 15.2 \\
\hline $\begin{array}{l}\text { Immunofluorescent } \\
\text { cells }(\%) \\
\text { EAC3-reactive cells }(\%)\end{array}$ & $\begin{array}{l}19.0 \\
15.2\end{array}$ & 0.0 & 2.0 & 12.0 & 25.0 \\
\hline EAC3-reactive cells (\%) & 15.2 & 3.3 & 1.2 & 16.0 & 22.4 \\
\hline
\end{tabular}

ferentiate into cells of the monocytic or granulocytic series. Degenerative changes appearing in the colonies by day 10 of culture precluded further study. The CFU precursor cells may also be progenitors of lymphoid cells. Chang, Hsieh, and Blankenship (18) could establish long-term lymphoid cell lines in fluid-phase cultures starting with normal peripheral blood. It is also known that pluripotential progenitor cells are not confined to the

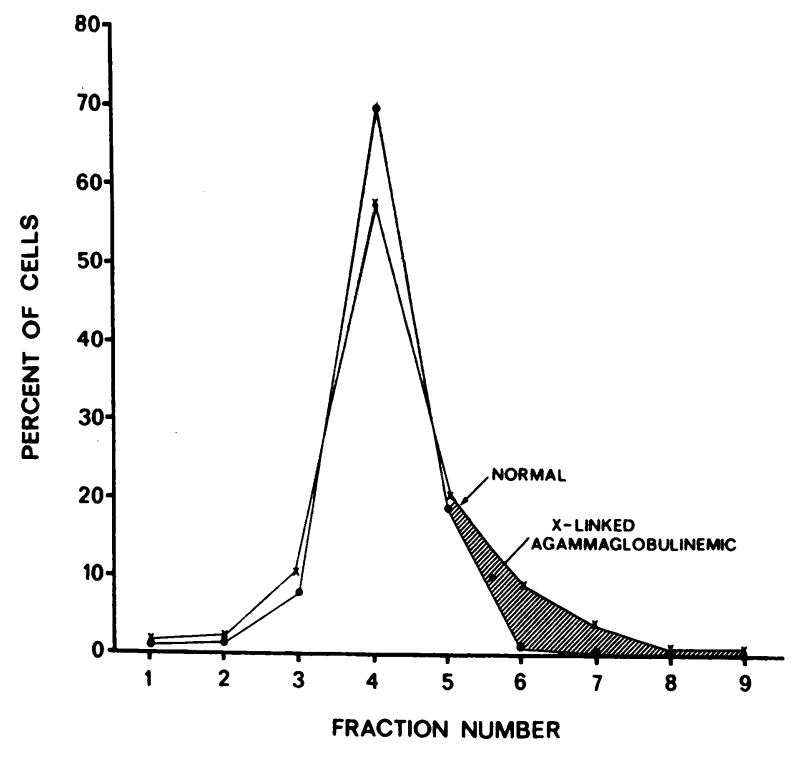

FIGURE 3 Relative distribution of lymphocytes from nor$\mathrm{mal}$ and X-linked agammaglobulinemic individuals after BSA gradient centrifugation. The hatched area between the two curves corresponds to the population of cells deficient in $\mathrm{X}$-linked agammaglobulinemia. 
TABLE VI

Relative Distribution of PBL after BSA Gradient Centrifugation in Normal Individuals and in Six Boys with Proved X-Linked Agammaglobulinemia

\begin{tabular}{|c|c|c|c|c|c|c|c|}
\hline \multirow{2}{*}{$\begin{array}{c}\text { BSA } \\
\text { frac- } \\
\text { tion }\end{array}$} & \multirow[b]{2}{*}{$\begin{array}{l}\text { Normal } \\
\text { adults }\end{array}$} & \multicolumn{6}{|c|}{$\mathrm{X}$-linked agammaglobulinemia patients } \\
\hline & & $\begin{array}{l}\text { L. A. } \\
21 \mathrm{yr}\end{array}$ & $\begin{array}{l}\text { S. D. } \\
5 \text { yr }\end{array}$ & $\begin{array}{l}\text { T. P. } \\
14 \mathrm{yr}\end{array}$ & $\begin{array}{l}\text { S. J. } \\
13 \mathrm{yr}\end{array}$ & $\begin{array}{l}\text { J. J. } \\
15 \mathrm{yr}\end{array}$ & $\begin{array}{l}\text { D. P. } \\
9 \mathrm{yr}\end{array}$ \\
\hline & $\%$ cells & \multicolumn{6}{|c|}{$\%$ cells } \\
\hline 1 & 0.6 & 0.9 & 0.9 & 0.3 & 0.5 & 0.4 & 0.3 \\
\hline 2 & 0.9 & 2.2 & 1.6 & 0.3 & 1.5 & 2.3 & 1.2 \\
\hline 3 & 10.6 & 8.6 & 8.0 & 7.2 & 9.3 & 12.2 & 3.4 \\
\hline 4 & 55.6 & 65.6 & 70.0 & 75.7 & 69.2 & 68.0 & 50.1 \\
\hline 5 & 20.4 & 22.0 & 18.6 & 15.4 & 18.4 & 16.9 & 27.2 \\
\hline 6 & 7.3 & 0.8 & 1.0 & 1.1 & 1.0 & 0.3 & 13.1 \\
\hline 7 & 2.7 & 0.0 & 0.0 & 0.0 & 0.0 & 0.0 & 2.5 \\
\hline 8 & 1.3 & 0.0 & 0.0 & 0.0 & 0.0 & 0.0 & 0.9 \\
\hline 9 & 0.8 & 0.0 & 0.0 & 0.0 & 0.0 & 0.0 & 0.4 \\
\hline
\end{tabular}

bone marrow, but do circulate in small numbers as evident from the ability of peripheral blood buffy coats to reconstitute lethally irradiated dogs and monkeys (19, 20). The exact number of circulating CFU precursor cells is difficult to determine. The figure obtained in the CFU assay ( $1.1 \%$ of cells in fractions $1-3$ ) is a minimum estimate of their number. Because progenitor cells do not respond to mitogens (21) while cells in fractions 1-3 do so to a moderate extent (Table II), it becomes obvious that the BSA gradient technique only partially separates the circulating progenitor cells found only in fractions 1-3 from committed lymphocytes found primarily in the next two fractions of the gradient.

Cells in fractions 4 and 5 of the gradient form the bulk $(70-80 \%)$ of circulating lymphocyte and exhibit $\mathrm{T}$ cell characteristics. These are vigorous response to stimulation by mitogens, antigens, and allogeneic cells (Fig. $1 c$ and $d)$; rosette formation with sheep red blood cells (Fig. $3 b)(22,23)$; moderate uptake of antigen (Fig. $3 a)(24)$; and the secretion of at least one cellular mediator for which we have assayed; namely, mitogenic factor. ${ }^{3}$

Cells in fractions $6-9$ of the gradient constitute less than $15 \%$ of the total number of circulating lymphocytes and exhibit $\mathrm{B}$ cell characteristics. These are immunofluorescent staining with anti-IgG and anti-Fc antisera (Fig. 3d) (25-27), rosette formation with EAC3 (Fig. $3 c$ ) (10), and absent proliferative response to antigenic stimuli (Fig. 1d) despite a high affinity for antigen (Fig. $3 a$ ). Because $\mathrm{B}$ cells are known not to proliferate in response to PHA while cells in fractions 6-9 consistently showed a moderate $\mathrm{PHA}$ response, and because only $60-70 \%$ of these cells formed rosettes with EAC3, a separation of $\mathrm{C} 3$-reactive cells was attempted. The results demonstrated that the PHA response in fractions

${ }^{3}$ Geha, R. S., and E. Merler. Unpublished observation.
6-9 is accounted for by a minor population of EAC3 nonreactive, immunofluorescent-negative lymphocytes similar to those found in fractions 4 and 5 .

Five of the six boys with proved X-linked agammaglobulinemia, where the definitive diagnosis was made on the basis of affected lateral male relatives (uncles and nephews), were found deficient in lymphocytes sedimenting in fractions $6-9$ of the gradient. None of these five had lymphocytes capable of immunofluorescent staining with anti-IgG and anti-Fc antisera or capable of rosette formation with EAC3. The sixth patient, D. P., behaved differently. He had a low-normal number of immunofluorescent cells and of EAC3-reactive cells, and his PBL showed a normal distribution after BSA gradient centrifugation. The laboratory findings in D. P. show some peculiar features. On several occasions, he had low levels of $\operatorname{IgA}(16 \mathrm{mg} / 100 \mathrm{ml})$ and of $\operatorname{IgM}(25 \mathrm{mg} /$ $100 \mathrm{ml}$ ). These levels were never found in any of the other five boys.

Of the four boys with the diagnosis of probable $\mathrm{X}$-linked agammaglobulinemia, two had no circulating $\mathrm{B}$ lymphocytes and two had a normal to high-normal number of circulating B lymphocytes. In none of these four boys was the diagnosis of $\mathrm{X}$-linked agammaglobulinemia proved by family genetics. In all four, the clinical picture and the lymph node biopsy were indistinguishable from what was found in the boys with verified X-linked agammaglobulinemia.

Although a number of investigators have also looked into the PBL of agammaglobulinemics for B lymphocytes using either immunofluorescent staining (28-31) or antigen binding as B cell markers (32), in none of the studies is the diagnosis of X-linked agammaglobulinemia established beyond doubt by the presence of affected lateral male relatives (uncles and nephews). Early onset of the disease and presence of affected brothers cannot be taken as proof of X linkage. While Grey, Rabellino, and Pirofsky (29), Cooper, Lawton, and Bockman (30), and Froland, Natvig, and Berdal (31) found a sharp reduction in the number of circulating immunofluorescent cells in the agammaglobulinemia cases they studied, Siegal, Pernis, and Kunkel (28) found a low-normal number of such cells in three of their six cases with presumed diagnosis of $\mathrm{X}$-linked agammaglobulinemia. It appears from our data that $\mathrm{X}$-linked agammaglobulinemia verified by family history may be a heterogeneous disease where in most of the cases (five out of six studies) there is not only absence of B-cell markers but complete physical absence of B lymphocytes as demonstrated by gradient centrifugation. In one form of the disease, which seems to consist of a minority of the patients (one case out of six studied), there is a near-normal number of circulating B lymphocytes as shown by immunofluorescence, rosette formation with $\mathrm{EAC} 3$, and gradient centrifugation. 
In conclusion, BSA gradient centrifugation separates human blood lymphocytes into three functionally distinct subpopulations rich in progenitor cells, $T$ cells, and $B$ cells, respectively. The method takes advantage of differences in cell densities and electrophoretic mobilities, the lowermost layers of the gradient having a much lower $\mathrm{pH}$ (5.1) than the uppermost layers (7.2). In the mouse, separation of $\mathrm{B}$ from $\mathrm{T}$ cells has been accomplished on the basis of their differing mobilities in an electric field (33). It is evident that the three subpopulations obtained by density gradients are not homogeneous. A further step toward attaining homogeneity of lymphocyte populations is achieved when BSA gradient centrifugation is followed by separation of $B$ from $T$ cells on the basis of their EAC3 reactivity. The simplicity of the method and its applicability to large numbers of lymphocytes make it a useful tool for the in vitro study of human $T$ and $B$ cell behavior and interaction in health and disease. This is exemplified by its application to the study of circulating B cells in the blood of boys with $\mathrm{X}$-linked agammaglobulinemia.

\section{ACKNOWLEDGMENTS}

The authors express their appreciation to the Blood Bank and Donor Service of the Children's Hospital Medical Center for providing the blood specimens, to the Massachusetts Biological Laboratories for providing the tetanus toxoid, to Dr. Robertson Parkman for providing the fluorescein-conjugated anti-Fc antiserum, to Dr. John Gatien for assisting with the immunofluorescent studies, to $\mathrm{Dr}$. Harvey Colten for providing the sheep erythrocyte intermediates and the goat antihuman $\mathrm{C} 3$ antiserum, to $\mathrm{Dr}$. Peter Schur for providing antisera, and to Dr. R. Maini for helpful suggestions on the method of purification of peripheral blood lymphocytes.

\section{REFERENCES}

1. Wilson, J. D., and G. J. V. Nossal. 1971. Identification of human $\mathrm{T}$ and $\mathrm{B}$ lymphocytes in normal peripheral blood and in chronic lymphocytic leukemia. Lancet. 2: 788.

2. Miller, J. F. A. P., and G. F. Mitchell. 1969. Thymus and antigen-reactive cells. Transplant. Rev. 1: 3 .

3. Fudenberg, H. H., R. A. Good, H. C. Goodman, W. Hitzig, H. G. Kunkel, I. M. Roitt, F. S. Rosen, D. S. Rowe, M. Seligmann, and J. R. Soothill. 1971. Primary immunodeficiencies: report of a World Health Organization committee. Pediatrics. 47: 927.

4. Unanue, E. R., H. M. Grey, E. Rabellino, P. Campbell, and J. Schmidtke. 1971. Immunoglobulins on the surface of lymphocytes. II. The bone marrow as the main source of lymphocytes with detectable surfacebound immunoglobulin. J. Exp. Med. 133: 1188.

5. Cooper, M. D., A. E. Gabrielsen, and R. A. Good. 1967. The role of the thymus and other central lymphoid tissues in immunological disease. Ann. Rev. Med. 18: 113.

6. Reif, A. E., and J. M. V. Allen. 1964. The AKR thymic antigen and its distribution in leukemias and nervous tissues. J. Exp. Med. 120: 413.
7. Raff, M. C. 1970. Two distinct populations of peripheral lymphocytes in mice distinguishable by immunofluorescence. Immunology. 19: 637.

8. Maini, R. N., A. D. M. Bryceson, R. A. Wolstencraft, and D. C. Dumonde. 1969. Lymphocyte mitogenic factor in man. Nature (Lond.). 224: 43.

9. Thorsby, E., and A. Bratlie. 1970. A rapid method for preparation of pure lymphocyte suspensions. Histocompatibility Testing 1970. Munksgaard, A/S, Copenhagen. 655.

10. August, C. S., E. Merler, D. O. Lucas, and C. A. Janeway. 1970. The response in vitro of human lymphocytes to phytohemagglutinin and to antigens after fractionation on discontinuous density of gradients of albumin. Cell. Immunol. $1: 603$.

11. Metcalf, D. 1970. Studies on colony formation in vitro by mouse bone marrow cells. II. Action of colony stimulating factor. J. Cell. Physiol. 76: 89.

12. Dicke, K. A., G. Tridente, and D. W. van Bekkum. 1969. The selective elimination of immunologically competent cells from bone marrow and lymphocyte cell mixtures. 3. In vitro test for detection of immunocompetent cells in fractionated mouse spleen cell suspensions and primate bone marrow suspensions. Transplantation. $8: 422$.

13. Bach, F. H., and N. K. Voynow. 1966. One-day stimulation in mixed leukocyte cultures. Science (Wash. D. C.). 153: 545 .

14. Gelfand, E. W., H. Borel, A. I. Berkel, and F. S. Rosen. 1973. Auto-immunosuppression: recurrent infections associated with immunologic unresponsiveness in the presence of an auto-antibody to IgG. Clin. Immunol. Immunopath. $1: 155$.

15. Borsos, T., and H. Rapp. 1970. Molecular Basis of Complement Action. Appleton-Century-Crofts, Inc., New York.

16. Bianco, C., R. Patrick, and V. Nussenzweig. 1970. A population of lymphocytes bearing a membrane receptor for antigen-antibody complement complexes. I. Separation and characterization. J. Exp. Med. 132: 702 .

17. Suter, E. R., H. Probst, and P. Dukor. 1972. The finestructure of complement receptor lymphocytes in mice. Eur. J. Immunol. 2: 189.

18. Chang, R. S., M. W. Hsieh, and W. Blankenship. 1971. Initiation and establishment of lymphoid cell lines from the blood of healthy persons. J. Natl. Cancer Inst. 47: 469.

19. Storb, R., R. B. Epstein, and E. D. Thomas. 1968. Marrow repopulating ability of peripheral blood cells compared to thoracic duct cells. Blood. 32: 662 .

20. Storb, R., R. B. Epstein, and E. D. Thomas. White Cell Transfusions. Editions du Centre National de la Recherche Scientifique. Paris. 61.

21. van Bekkum, D. W., H. Balner, K. A. Dicke, and L. M. Von Pulten. 1969. Experimental aspects of bone marrow transplantation in primates. Transplant. Proc. $1: 25$.

22. Brain, P., J. Gordon, and W. A. Willets. 1970. Rosette formation by peripheral lymphocytes. Clin. Exp. Immunol. 6: 681.

23. Silveira, N. P. A., N. F. Mendes, and M. E. A. Tolnai. 1972. Tissue localization of two populations of human lymphocytes distinguished by membrane receptors. $J$. Immunol. 108: 1456.

24. Merler, E., and M. Silberschmidt. 1972. Uptake of antigen by human lymphocytes. Immunology. 22: 821 .

25. Pernis, B., L. Forni, and L. Amante. 1970. Immuno- 
globulin spots on the surface of rabbit lymphocytes. J. Exp. Med. 132: 1001.

26. Paraskevas, F., S. T. Lee, K. B. Orr, and L. G. Israels 1972. A receptor for $\mathrm{Fc}$ on mouse B-lymphocytes. $J$. Immunol. 108 : 1319.

27. Papamichail, M., J. C. Broom, and E. J. Holbrow. 1971. Immunoglobulins on the surface of human lymphocytes. Lancet. $2: 850$.

28. Siegal, F. P., B. Pernis, and H. G. Kunkel. 1971. Lymphocytes in human immunodeficiency states: a study of membrane-associated immunoglobulins. Eur. J. Immunol. 1: 482.

29. Grey, H. M., E. Rabellino, and B. Pirofsky. 1971. Immunoglobulins on the surface of lymphocytes. IV. Distribution in hypogammaglobulinemia, cellular immune deficiency, and chronic lymphatic leukemia. J. Clin. Invest. $50: 2368$.

30. Cooper, M. D., A. Lawton, and D. E. Bockman. 1971. Agammaglobulinaemia with B lymphocytes: Specific defect of plasma-cell differentiation. Lancet. 2 : 791.

31. Froland, S., J. B. Natvig, and P. Berdal. 1971. Surface-bound immunoglobulin as a marker of B lymphocytes in man. Nat. New Biol. 234: 251.

32. Naor, D., Z. Bentwich, and G. Cividelli. 1969. Inability of peripheral lymphoid cells of agammaglobulinaemic patients to bind radioiodinated albumins. Aust. J. Exp. Biol. Med. Sci. 47 : 759 .

33. Wioland, M., D. Sabolovic, and C. Burg. 1972. Electrophoretic mobilities of $\mathrm{T}$ and B cells. Nat. New Biol. $237: 274$. 